\title{
Why Title IX Does Not Preclude Section 1983 Claims
}

\author{
Michael A. Zwibelman†
}

A victim of sexual harassment by a teacher may wish to sue the teacher, the principal, the members of the school board, the superintendent, the school district itself, and the municipality in which the school district operates. Typically, the plaintiff will want to bring two types of claims: (1) constitutional claims under 42 USC \& 1983, ${ }^{1}$ which provides a cause of action against state actors for violations of the Constitution and federal laws; and (2) a claim under Title IX of the Higher Education Amendments of $1972,{ }^{2}$ either as an implied right of action under Title IX itself ${ }^{3}$ or as a Section 1983 claim predicated on Title IX.4

Lower courts disagree as to whether Title IX precludes a plaintiff from bringing Constitution-based Section 1983 claims as well as Section 1983 claims predicated on Title IX itself. Because the distinction between Constitution-based and statute-based Section 1983 claims is critical, it is important to understand how a statute like Title IX can preclude both a Section 1983 claim predicated on Title IX itself as well as a Section 1983 claim predicated on a constitutional right. The Supreme Court set out the important test in Middlesex County Sewerage Authority $v \mathrm{Na}$ -

† B.A. 1995, Stanford University; M.P.A. Candidate 1999, Princeton University; J.D. Candidate 1999, The University of Chicago.

' Section 1983 provides:

Every person who, under color of any statute, ordinance, regulation, custom, or usage, of any State ... . subjects, or causes to be subjected, any citizen of the United States ... to the deprivation of any rights, privileges, or immunities secured by the Constitution and laws, shall be liable to the party injured in an action at law, suit in equity, or other proper proceeding for redress.

42 USC \& 1983 (1994).

2 Title IX provides that "[n]o person in the United States shall, on the basis of sex, be excluded from participation in, be denied the benefits of, or be subjected to discrimination under any education program or activity receiving Federal financial assistance." Pub L No 92-318, 86 Stat 235 (1972), codified at 20 USC $\$ 1681$ (a) (1994).

${ }^{3}$ See Cannon $v$ University of Chicago, 441 US 677, 689 (1979) (holding that individuals have a private right of action under Title IX).

4 See Blessing v Freestone, 117 S Ct 1353, 1359 (1997) ("In order to seek redress through $\S 1983$... a plaintiff must assert the violation of a federal right, not merely a violation of federal law."); Maine $v$ Thiboutot, 448 US 1, 4 (1980) (holding that Section 1983 claims may be predicated on federal statutory rights); Cannon, 441 US at $688 \mathrm{n} 9$, 693-94 (acknowledging that Title IX "create[s] a federal right in favor of the plaintiff"). 
tional Sea Clammers Association. ${ }^{5}$ Under the Sea Clammers comprehensiveness test, ${ }^{6}$ Title IX claims-that is, private rights of action brought directly under Title IX-can preclude Section 1983 claims predicated on Title IX if Title IX's remedial scheme (the termination of federal funding ${ }^{7}$ ) is sufficiently comprehensive to demonstrate Congress's intent to preclude the statutory-based Section 1983 remedy. ${ }^{8}$ Title IX can also preclude Constitutionbased Section 1983 claims, ${ }^{9}$ but only if the constitutional rights upon which the Section 1983 claim is predicated are virtually identical to the rights conferred by Title IX and if Congress intended the remedial scheme of Title IX to serve as the exclusive means by which a plaintiff might vindicate her rights. ${ }^{10}$

Whether a plaintiff can bring both Title IX and Section 1983 claims has important implications for her ability to vindicate her statutory and constitutional rights. The Supreme Court, for example, has not settled a disagreement among lower courts as to whether individual defendants-such as teachers, principals, and school board members-are proper defendants under Title IX. If individuals are not proper defendants under Title IX, and if a plaintiff were not able to bring her Section 1983 claims against those individuals because Title IX precludes all Section 1983 claims, then she would be unable to reach the individuals responsible for her injuries.

Plaintiffs may also want to bring both Title IX and Section 1983 claims in order to take advantage of Section 1983's lower burden of proof for supervisory liability. For example, a plaintiff may find it easier to prove that the principal, superintendent, or school district were responsible for a teacher's misconduct under Section 1983, which generally requires a showing of gross negligence, than under Title IX, which requires a showing of actual

- 453 US 1 (1981).

- Id at 20.

7 "The express statutory means of enforcement is administrative: The statute directs federal agencies who distribute education funding to establish requirements to effectuate the nondiscrimination mandate, and permits the agencies to enforce those requirements through 'any ... means authorized by law,' including ultimately the termination of federal funding." Gebser v Lago Vista Independent School District, 118 S Ct 1989, 1994 (1998), quoting 20 USC $\$ 1682$ (1994).

${ }^{8}$ For a concrete example of what the Court means by a "sufficiently comprehensive" remedial scheme, see note 18 . See also text accompanying notes 84-87.

- Examples of Constitution-based Section 1983 claims include claims predicated on the right to bodily integrity under the Due Process Clause, or the right to be free from intentional discrimination on the basis of sex under the Equal Protection Clause.

${ }^{10}$ See Smith $v$ Robinson, 468 US 992, 1008-11 (1984). See also notes $22-29$ and accompanying text and text accompanying note 89 . 
knowledge plus deliberate indifference on the part of supervisory officials and institutions.

Part I of this Comment provides an exposition of the law of Section 1983 preclusion and highlights the lower courts' deviations from Supreme Court precedent. Parts II and III respectively argue that Title IX precludes neither Section 1983 claims based on Title IX itself nor those based on constitutional rights. These two Parts also demonstrate that while some courts may have reached the legally correct result in Section 1983 preclusion cases, no court has applied the legal tests in a way that is wholly consistent with Supreme Court precedent. Part IV discusses the impact that Title IX's potential foreclosure of Section 1983 claims has on plaintiffs and defendants in sexual harassment and discrimination lawsuits. This Comment concludes that the Supreme Court's test for implied statutory rights of action may reduce the Section 1983 preclusion analysis to a mere formality: a judicial determination that a statute creates an implied right of action compels the conclusion that Congress did not intend to preclude Section 1983 claims.

\section{AN OVERVIEW OF SECTION 1983 PRECLUSION}

When confronting the question of whether a particular statute precludes Section 1983 claims, the Supreme Court applies two distinct tests depending upon the nature of the Section 1983 claim. For Section 1983 claims predicated on statutory rights, ${ }^{11}$ the Supreme Court applies the Sea Clammers comprehensiveness test to determine whether Congress implicitly intended to preclude the Section 1983 cause of action by providing a comprehensive remedial scheme in the statute itself. ${ }^{12}$ For Section 1983 claims predicated on constitutional rights, the Supreme Court applies the two-pronged test from Smith $v$ Robinson. ${ }^{13}$ This test analyzes, first, the similarity of the rights underlying the Section 1983 claim to the rights conferred by the relevant statute, and, second, whether Congress intended to preclude the Constitutionbased Section 1983 claim. ${ }^{14}$

"See Maine $v$ Thiboutot, 448 US 1, 4 (1980) ("TT]he § 1983 remedy broadly encompasses violations of federal statutory as well as constitutional law.").

${ }^{12}$ See Wilder $v$ Virginia Hospital Association, 496 US 498, 521 (1990), quoting Sea Clammers, 453 US at 20 . Congress, of course, may foreclose Section 1983 claims explicitly in a particular statute.

${ }^{13} 468$ US 992 (1984).

" Id at 1008-09. 


\section{A. Preclusion of Statute-Based Section 1983 Claims}

One year after Maine $v$ Thiboutot ${ }^{15}$ which granted plaintiffs the ability to bring Section 1983 claims predicated on federal statutory rights, ${ }^{16}$ the Court limited the reach of the decision. In Sea Clammers, the Court held that Section 1983 claims predicated on two federal environmental statutes were precluded by the "unusually elaborate" enforcement provisions in the statutes themselves. ${ }^{17}$ In other words, the statutes' remedial schemes were "sufficiently comprehensive" to evidence Congress's intent to preclude Section 1983 claims predicated upon those statutes. ${ }^{18}$

Two underlying rationales help explain the Sea Clammers holding. First, Sea Clammers addressed only statute-based Section 1983 claims, not those resting on constitutional violations. Since its passage in 1871, Section 1983 has afforded individuals protection against the conduct of state actors who have violated the individuals' constitutional rights. ${ }^{19}$ It was not until 1980 that the Supreme Court recognized that violations of federal law would also be actionable under Section $1983 .^{20}$ The decision in Sea Clammers, then, can be seen as an attempt to constrain the Thiboutot departure from the century-old interpretation of Section 1983. Second, Sea Clammers hinges on congressional intent. Specifically, the comprehensiveness analysis aims to effect Congress's desire to prevent plaintiffs from circumventing the remedial schemes of federal statutes by bringing Section 1983 claims. ${ }^{21}$

${ }^{13} 448$ US 1 (1980).

${ }^{16}$ Id at 4.

${ }^{17} 453$ US at 13.

${ }^{18}$ Id at 20. The environmental statutes at issue in Sea Clammers-the Federal Water Pollution Control Act, 33 USC $\S \$ 1251$ et seq (1994), and the Marine Protection, Research, and Sanctuaries Act, 33 USC $\$ \S 1401$ et seq (1994)-contain detailed provisions that authorize private citizens to sue for injunctions to enforce the acts. See Sea Clammers, 453 US at $6,14,17$. The statutes also require citizen plaintiffs to give sixty days notice to the United States Environmental Protection Agency, the State, and any alleged violator. See id at 6, 14.

${ }^{19}$ For a historical summary of Section 1983 actions, see Nancy Levit, Preemption of Section 1983 by Title VII: An Unwarranted Deprivation of Remedies, 15 Hofstra L Rev 265, 266-76 (1987).

${ }^{2}$ Thiboutot, 448 US at 4.

${ }^{21}$ See, for example, Sea Clammers, 453 US at 20 \& n 30, quoting Chapman v Houston Welfare Rights Organization, 441 US 600, 673 n 2 (1979) (Stewart dissenting) ("[When] a state official is alleged to have violated a federal statute which provides its own comprehensive enforcement scheme, the requirements of that enforcement procedure may not be bypassed by bringing suit directly under $\S 1983$. .); Meyerson v Arizona, 507 F Supp 859, 864 (D Ariz 1981) ("[T]he remedial provision of $\S 1983$ cannot be used to circumvent the remedial provisions of the Revenue Sharing Act[, 31 USC $\S 1242$ (1976)]."). 


\section{B. Preclusion of Constitution-Based Section 1983 Claims}

For Section 1983 claims predicated on constitutional rights, the Supreme Court has applied a different preclusion test-the two-pronged test developed in Smith ${ }^{22}$ Smith involved the Education of the Handicapped Act ("EHA"), ${ }^{23}$ which was "set up by Congress to aid the States in complying with their constitutional obligations to provide public education for handicapped children ${ }^{.24}$ Because the EHA conferred a right upon a plaintiff that was "virtually identical" to the plaintiff"s equal protection right to a publicly financed special education, the Court held that Section 1983 claims predicated on the Equal Protection Clause were precluded by the EHA. ${ }^{25}$

The first prong of the Smith test, then, requires courts to determine whether the constitutional right upon which the Section 1983 claim is predicated is "virtually identical" to the right conferred by the federal statute. ${ }^{26}$ If the Section 1983 constitutional right is not virtually identical, then the statute does not preclude the Section 1983 claim unless the statute explicitly indicates otherwise. ${ }^{27}$

If the constitutional right upon which the Section 1983 claim is based is virtually identical to rights conferred by the statute, then courts must apply the second prong of the Smith test, which asks whether Congress intended the statute to be the "exclusive avenue through which a plaintiff may assert [constitutional]

22468 US at 1008-09 (noting that a statutory remedy precludes Constitution-based Section 1983 claims that are virtually identical to the statutory claims if Congress intends such a result).

20 USC $\S \S 1400$ et seq (1982).

« 468 US at 1009.

${ }^{25}$ Id. Prior to the enactment of the EHA, two district courts issued consent decrees requiring schools to provide handicapped children with access to public education. Mills $v$ Board of Education of the District of Columbia $v$ Pennsylvania, 348 F Supp 866 (D DC 1972); Pennsylvania Association for Retarded Children v Pennsylvania, 334 F Supp 1257 (E D Pa 1971). These cases played a substantial role in the development of the EHA. See Board of Education of Hendrick Hudson Central School District $v$ Rowley, 485 US 176, 192 (1982) (describing this development).

${ }^{2} 468$ US at $1008-09$.

${ }^{27}$ Id at 1009. The Sixth Circuit accurately presented the two-pronged Smith test in Lillard $v$ Shelby County Board of Education, 76 F3d 716 (6th Cir 1996), and demonstrated how both prongs must be satisfied before preclusion of Constitution-based Section 1983 claims. Id at 723 (holding that courts may foreclose a Constitution-based Section 1983 claim only if the "constitutional claims ... [are] virtually identical to the statutory ... claims, and [if the] legislative history indicat[es] a congressional intention to preclude reliance on Section 1983 as a remedy") (emphasis added). See also Levit, 15 Hofstra L Rev at 282-83 (cited in note 19) (noting that many courts have adopted the "independent rights theory," which allows a plaintiff to sue under both the statute and Section 1983, provided that the Section 1983 claims are predicated on "a right independently guaranteed by the Constitution"). 
claims. ${ }^{\$ 28}$ If so, the statute precludes the Section 1983 claim. ${ }^{29}$ Under Smith, then, even if a plaintiff raises a Section 1983 claim predicated on a constitutional right that is identical to the right conferred by a statute, that statute will not preclude the Section 1983 claim unless the court finds that Congress intended such preclusion.

\section{Summary of Section 1983 Preclusion Law}

Because the Supreme Court has announced separate tests for statute-based and Constitution-based Section 1983 claims in Sea Clammers and Smith, respectively, courts confronted with the Section 1983 preclusion issue must first determine how to classify the particular Section 1983 claims involved. Section 1983 claims fall into three distinct categories: (1) Section 1983 claims predicated on statutory rights; (2) Section 1983 claims predicated on constitutional rights that are not virtually identical to the rights conferred by the federal statute under which the plaintiff seeks to bring a Section 1983 claim; and (3) Section 1983 claims based on constitutional rights that are virtually identical to rights conferred by the federal statute under which the plaintiff seeks to bring a Section 1983 claim.

If the cause of action is a Section 1983 claim predicated on statutory rights, then courts must apply the Sea Clammers comprehensiveness test. If the Section 1983 action is predicated on a constitutional right that is not virtually identical to a right conferred by the statute in question, then courts must conclude that the statute does not preclude the Constitution-based claim, unless Congress clearly intended otherwise. If the constitutional Section 1983 claim is predicated on a constitutional right that is virtually identical to a right conferred by the statute, then courts must apply the second prong of the Smith test to determine whether Congress intended to preclude Constitution-based Section 1983 claims.

\section{Lower Courts' Deviations from Supreme Court Precedent}

Ten lower courts in nine judicial circuits have faced the question of Title IX's preclusion of Section 1983 claims:

468 US at 1009.

${ }^{2}$ Congressional intent can manifest itself in three ways: (1) Congress can explicitly provide that the statute's remedial scheme shall be the exclusive avenue for relief; (2) the legislative history may provide strong evidence that Congress intended exclusivity; or (3) a detailed, elaborate remedial scheme may provide evidence that Congress implicitly intended exclusivity. See Part III.B. 
DOES TITLE IX PRECLUDE SECTION 1983 CLAIMS?

\begin{tabular}{|l|l|l|}
\hline \multicolumn{1}{|c|}{ TYPE OF CLAIM } & \multicolumn{1}{|c|}{ YES } & \multicolumn{1}{c|}{ NO } \\
\hline SECTION 1983 & Lakoski (5th Cir 1995) & Lillard (6th Cir 1996) $^{35}$ \\
CLAIMS & Waid (7th Cir 1996) $^{31}$ & Crawford (8th Cir 1997) $^{36}$ \\
PREDICATED & Seamons (10th Cir 1996) & Oona R.-S. (N D Cal 1995) $^{37}$ \\
ON TITLE IX & Bruneau (N D NY 1996) & \\
\hline Bougher (W D Pa 1989) & \\
\hline $\begin{array}{l}\text { SECTION 1983 } \\
\text { PRAIMS }\end{array}$ & Williams (3d Cir 1993) & Lillard (6th Cir 1996) \\
CONSTITUTIONAL & Waid (7th Cir 1996) & Crawford (8th Cir 1997) \\
RIGHTS & Mennone (D Conn 1995) & Seamons (10th Cir 1996) \\
\hline
\end{tabular}

No two courts have applied the same analysis, ${ }^{44}$ and no court has applied the law in the methodical fashion described above. In particular, lower courts have deviated from Supreme Court precedent in four areas. First, some lower courts have failed to distinguish between statute-based and Constitution-based Section 1983 claims when applying the Sea Clammers doctrine. In opinions since Sea Clammers, the Supreme Court has been careful to distinguish between Section 1983 claims predicated on

${ }^{30}$ Lakoski $v$ James, 66 F3d 751, 755-58 (5th Cir 1995). The plaintiff in Lakoski brought a Section 1983 claim predicated on Title IX itself. Therefore, the court's conclusion that Title IX forecloses Section 1983 claims based on Title IX itself is a holding of the case. For the sake of brevity, the remaining footnotes for the chart will include parentheticals indicating simply "holding" or "dicta."

${ }^{31}$ Waid v Merrill Area Public Schools, 91 F3d 857, 862 (7th Cir 1996) (dicta).

${ }^{32}$ Seamons $v$ Snow, 84 F3d 1226, 1234 n 8 (10th Cir 1996) (dicta).

* Bruneau v South Kortright Central School District, 935 F Supp 162, 178-79 (N D NY 1996) (holding).

* Bougher $v$ University of Pittsburgh, 713 F Supp 139, 146 (W D Pa 1989) (holding).

${ }^{35}$ Lillard $v$ Shelby County Board of Education, 76 F3d 716, 723 (6th Cir 1996) (dicta).

* Crawford $v$ Davis, 109 F3d 1281, 1284 (8th Cir 1997) (holding).

${ }^{\prime}$ Oona R.-S. by Kate S. v Santa Rosa City Schools, 890 F Supp 1452, 1462 (N D Cal 1995) (holding), affd, Oona R.-S. by Kate S. v McCaffrey, 122 F3d 1207 (9th Cir 1997), order withdrawn and superseded on denial of rehg, 143 F3d 473 (9th Cir 1998), amended on denial of rehg, 1998 US App LEXIS 8805, petition for cert filed, 67 USLW 3083 (June 19, 1998) (No 98-101).

36 Williams v School District of Bethlehem, 998 F2d 168, 176 (3d Cir 1993) (holding).

91 F3d at 862 (holding).

to Mennone v Gordon, 889 F Supp 53, 59-60 (D Conn 1995) (holding).

76 F3d at 723-24 (holding).

42109 F3d at 1284 (holding).

44 F3d at 1234 (holding).

"Although the Seventh Circuit in Waid described the Third Circuit's approach in Williams as "persuasive," the Seventh Circuit applied a much more thorough analysis of the tests. Waid, 91 F3d at 861-63. Similarly, the Tenth Circuit in Seamons cited the Sixth Circuits opinion in Lillard approvingly, although the Seamons court failed to apply the second prong of the Smith "virtually identical" test. Seamons, 84 F3d at 1234. 
statutory rights and those based on constitutional rights; specifically, the Court has applied the Sea Clammers comprehensiveness test in the former cases but never in the latter cases. ${ }^{45}$ Some lower courts, however, have improperly applied the Sea Clammers comprehensiveness test to Constitution-based Section 1983 claims in the context of a Title IX preclusion analysis. ${ }^{46}$ Instead, the courts should have applied the Smith test. Applying Sea Clammers to Constitution-based claims is problematic, because the Sea Clammers case involved a statute-based Section 1983 claim, and, therefore, did not address the issue of Constitutionbased Section 1983 preclusion. Moreover, when courts conflate the two types of Section 1983 claims and apply the Sea Clammers test to constitutional claims, they overlook Sea Clammers' narrow holding. The Sea Clammers Court intended only to limit the reach of Thiboutot; to disturb the historical importance of vindicating constitutional rights through Section 1983 actions. ${ }^{47}$

Second, some lower courts have failed to distinguish among different types of Constitution-based claims when applying the Smith test. In Smith, the Supreme Court required that each Constitution-based Section 1983 claim be analyzed separately under a two-pronged test; ${ }^{48}$ lower courts, however, often have conflated multiple constitutional claims. In Williams $v$ School District of Bethlehem, ${ }^{49}$ for example, the Third Circuit failed to distinguish between the plaintiff's equal protection and due process claims and, without applying the Smith two-pronged test, held that both constitutional claims were precluded. ${ }^{50}$ Similarly, the Tenth Circuit, in Seamons $v$ Snow, ${ }^{51}$ did not separately assess the plaintiff's multiple Constitution-based Section 1983 claims. Faced with several distinct constitutional allegations under Section $1983,{ }^{52}$ the

${ }^{45}$ See, for example, Blessing $v$ Freestone, 117 S Ct 1353, 1360 (1997) (applying the comprehensiveness test to Section 1983 claims based on Title IV-D of the Social Security Act); Wilder, 496 US at 520-21 (applying the comprehensiveness test to Section 1983 claims based on the Medicaid Act); Wright $v$ City of Roanoke Redevelopment \& Housing Authority, 479 US 418, 424, 429 (1987) (applying the comprehensiveness test to Section 1983 claims based on the Brooke Amendment to the Housing Act of 1937).

${ }^{46}$ See Williams, 998 F2d at 176; Mennone, 889 F Supp at 59-60.

${ }^{47}$ See text accompanying notes 19-21. See also Monroe v Pape, 365 US 167, 180 (1961) (discussing the importance of Section 1983 in protecting federal rights); Levit, 15 Hofstra $\mathrm{L}$ Rev at 266-68 (cited in note 19).

${ }^{48}$ See Part I.B.

${ }^{49} 998$ F2d 168 (3d Cir 1993).

${ }^{30}$ Id at 176.

${ }^{31} 84$ F3d 1226 (10th Cir 1996).

${ }^{32}$ In Seamons, the plaintiff alleged that "[d]efendants are liable under [Section 1983] for violating [plaintiff's] constitutional rights to procedural due process, substantive due process, freedom of association, freedom of speech, familial association, and for violating [plaintiff's] right to equal education and equal protection." Id at 1230. 
Tenth Circuit should have applied the Smith two-pronged test to each individual constitutional claim.

Third, some courts have applied Smith incorrectly by failing to adhere to the "virtually identical" language of the first prong of the test. The district court in Mennone $v$ Gordon, ${ }^{53}$ for example, inquired whether the different constitutional claims were based on the same set of underlying facts. ${ }^{54}$ Similarly, the Seventh Circuit in Waid $v$ Merrill Area Public Schools ${ }^{55}$ held that a plaintiff could not claim that a "single set of facts" led to causes of action under both Title IX and Section $1983 .{ }^{56}$ Neither the Mennone nor the Waid court explicitly applied the "virtually identical" prong of the Smith test. ${ }^{57}$ Instead of comparing the right under Title IX (freedom from sex discrimination) with the constitutional rights underlying the Section 1983 claims to determine whether they were virtually identical, the courts inquired as to whether all of the claims (Title IX and Section 1983) arose out of the same set of underlying facts.

There are two problems with the approaches taken by the Mennone and Waid courts. First, the Supreme Court has articulated a specific test in Smith to be applied in Constitution-based Section 1983 preclusion cases, and lower courts must follow it. Second, a "same set of facts" test used by these courts requires them to venture too far from the underlying purposes of the Smith "virtually identical" prong. Two claims may arise out of the same set of facts but may be completely independent of each other; that is, Congress may intend to provide overlapping remedies for claims that arise out of the same set of facts but that are not virtually identical. A plaintiff, for example, may bring a Title IX claim for sexual harassment as well as a Section 1983 claim predicated on the substantive due process right to bodily integrity. ${ }^{58}$ Both claims arise out of the same set of underlying facts (the sexual assault), but the rights involved are not virtually identical, because Title IX confers a right to be free from discrimination on the basis of sex and does not speak to the issue of bodily integrity.

889 F Supp 53 (D Conn 1995).

* Id at $60 \mathrm{n} 4$.

so 91 F3d 857 (7th Cir 1996).

${ }^{36}$ Id at 862.

${ }^{37}$ However, the Seventh Circuit in Waid, without invoking Smith, noted that the plaintiff's constitutional Section 1983 claim was "essentially identical" to her rights under Title IX. Id at 861.

${ }^{58}$ See, for example, the allegations in Seamons, described at note 52. 
Finally, contrary to the methodical Section 1983 preclusion analysis presented in this Part, some lower courts have concluded that Title IX precludes Section 1983 claims after merely conducting a summary comprehensiveness analysis. The district court in Oona R.-S. by Kate S. $v$ Santa Rosa City Schools, ${ }^{59}$ criticized three courts for failing to undertake the "thorough analysis of the comprehensiveness of Title IX's remedial scheme required to establish Congressional intent to foreclose a section 1983 remedy. ${ }^{360}$ The Tenth Circuit also summarily concluded in dicta that Title IX precludes Section 1983 claims predicated on Title IX itself. $^{61}$ Regardless of the nature of the Section 1983 claim, courts must carefully analyze the remedial scheme of the statute in question and make a careful inquiry into whether Congress intended a statute to preclude Section 1983 claims.

\section{Title IX Does Not PREClude Section 1983 Claims PREDICATED ON TITLE IX ITSELF}

This Part will argue that a faithful reading of Sea Clammers and its successor line of cases leads to the conclusion that Title IX does not preclude Section 1983 claims predicated on Title IX itself. This conclusion follows from two principal arguments. First, the Supreme Court on repeated occasions has made clear that courts must invoke a strong presumption against Section 1983 preclusion. Second, courts must limit their comprehensiveness analysis to Title IX's explicit remedial scheme and may not consider either judicially created remedies or remedies that may be available in other statutes.

\section{A. Courts Must Invoke a Strong Presumption Against Preclusion}

When analyzing whether Title IX precludes Section 1983 claims predicated on Title IX itself, courts must first acknowledge the strong presumption against preclusion. In each Section 1983 preclusion case since Sea Clammers, the Court has expressed its

890 F Supp 1452 (N D Cal 1995). Subsequent case history discussed in note 37.

${ }^{\infty} 890 \mathrm{~F}$ Supp at 1461-62 n 3, citing Bougher, 713 F Supp at 146 (concluding without analysis that Title IX "contains its own remedies and is implemented through its own procedural scheme"); Pfeiffer $v$ Marion Center Area School District, 917 F2d 779, 789 (3d Cir 1990) (accepting, without analysis, that Sea Clammers foreclosed plaintiff's Section 1983 constitutional claims); Mabry $v$ State Board for Community Colleges and Occupational Education, 597 F Supp 1235, 1239 (D Colo 1984) (stating without analysis that it was "convinced" that plaintiff"s remedies under Title IX would have been comprehensive had she prevailed on that claim).

${ }^{61}$ Seamons, 84 F3d at 1234 n 8. 
reluctance to preclude the Section 1983 cause of action. In $\mathrm{Li}$ vadas $v$ Bradshaw, ${ }^{62}$ for example, the Court declared statutebased Section 1983 claims to be "generally and presumptively available" and described preclusion as an "exceptional case[ ]."63 Similarly, the Court in Wilder $v$ Virginia Hospital Association ${ }^{64}$ asserted that "[w]e do not lightly conclude that Congress intended to preclude reliance" on statute-based Section 1983 claims. ${ }^{65}$ The Court also noted in Wright $v$ City of Roanoke Redevelopment \& Housing Authority ${ }^{66}$ that evidence of legislative history supporting Section 1983 preclusion must "raise a clear inference" of such intent. ${ }^{67}$ Most recently, the Court held in Blessing $v$ Freestone ${ }^{68}$ that defendants would have to make the "difficult showing" that allowing statute-based Section 1983 claims would be inconsistent with the statute's remedial scheme. ${ }^{69}$ Commentators agree that the burden of establishing Section 1983 preclusion is a heavy one. ${ }^{70}$

\section{B. Courts Must Limit Their Comprehensiveness Analysis to Title IX's Explicit Remedial Scheme}

Once courts acknowledge the strong presumption against preclusion in statute-based Section 1983 cases, they must define what constitutes proof that Title IX's remedial scheme is comprehensive enough to demonstrate that Congress intended to preclude a Section 1983 cause of action. This Part argues that courts must apply the Sea Clammers comprehensiveness test only to the statute's express remedial scheme, without considering evidence of overlapping statutes or judicially created remedies.

512 US 107 (1994).

Id at 133.

at 496 US 498 (1990).

${ }^{65}$ Id at 520 (internal citations omitted).

os 479 US 418 (1987).

${ }^{67}$ Id at 425. The Wright Court also expressed disapproval of the Fourth Circuit's "summary conclusion" that the statute at issue foreclosed statute-based Section 1983 claims. Id at 424.

117 S Ct 1353 (1997).

Id at 1362.

${ }^{70}$ See, for example, Cass R. Sunstein, Section 1983 and the Private Enforcement of Federal Law, 49 U Chi L Rev 394, 420-21 (1982) (arguing that defendants must make a "fairly powerful showing of contrary legislative intent" before a court may preclude statute-based Section 1983 claims). Professor Sunstein also argues that "it is preferable for the courts to disfavor repeal of section 1983 by implication" than to undertake an errorprone "case-by-case inquiry" into congressional intent. Id at 425. See also Myron D. Rumeld, Note, Preclusion of Section 1983 Causes of Action by Comprehensive Statutory Remedial Schemes, 82 Colum L Rev 1183, 1189 (1982) (arguing that "intemperate application of comprehensiveness would render the statutory reference of section 1983 without effect and eviscerate the Thiboutot decision ${ }^{n}$ ). 
The Supreme Court consistently has stressed that the comprehensiveness analysis is limited to the express remedial scheme contained in the statute itself. In Wright, for example, the Court stated that Section 1983 provides a remedial cause of action for federal statutory rights unless the "state actor demonstrates by express provision or other specific evidence from the statute itself that Congress intended to foreclose such private enforcement. " Similarly, the Court in Wilder reiterated the rule that Congress must have precluded the statute-based Section 1983 claim "in the enactment itself" before a court may conclude that preclusion is warranted. ${ }^{72}$

Despite this language, some lower courts have looked to other statutory remedies that may be available to plaintiffs when applying the Sea Clammers comprehensiveness test. For example, the Fifth Circuit recognized in Lakoski $v$ James $^{73}$ that the comprehensiveness test requires courts to "look to the remedial measures provided by the statute itself," but nevertheless proceeded to consider factors outside of Title IX's remedial scheme. ${ }^{74}$ Although the Lakoski court acknowledged that it was unable to conclude "that Title IX provides a remedial scheme sufficiently comprehensive to indicate by itself that Congress intended to foreclose $\S 1983$ suits based upon rights created by Title IX," it maintained that it "ought not . . . confine [its] inquiry into congressional intent to the remedies afforded by Title IX. ${ }^{m 5}$ Instead, the Fifth Circuit concluded that because other civil rights statutes, such as Title VII, provide plaintiffs and courts with a "variety of tools to remedy employment discrimination," it was justified in precluding Section 1983 claims predicated on Title IX ${ }^{76}$

It could be argued that the Fifth Circuit's decision in Lakoski to consider the availability of other statutory remedies makes intuitive sense and warrants a change in the "in the enactment itself" language of the Supreme Court case law. The Fifth Circuit's use of other employment discrimination statutes in its preclusion

" 479 US at 423 (emphasis added). The Court in Wright limited its comprehensiveness analysis to the Housing Act of 1937, 42 USC $\$ \S 1401$ et seq (1970), and concluded that "[t]here [was] nothing ... found in the Brooke Amendment or elsewhere in the Housing Act" that evidenced congressional intent to supplant the Section 1983 remedy. Id at 427 . Accord Suter v Artist M., 503 US 347, 355-56 (1992) ("We have subsequently recognized that $\S 1983$ is not available to enforce a violation of a federal statute where Congress has foreclosed such enforcement of the statute in the enactment itself.") (citations omitted).

${ }^{72} 496$ US at 508.

${ }^{73} 66$ F3d 751 (5th Cir 1995).

74 Id at 754.

${ }^{75}$ Id at 755.

${ }^{76}$ Id. 
analysis, however, ignores the strong language used by the Supreme Court in North Haven Board of Education v Bell. ${ }^{77}$ In Bell, the Supreme Court stated that "even if alternative remedies are available and their existence is relevant ... this Court repeatedly has recognized that Congress has provided a variety of remedies, at times overlapping, to eradicate employment discrimination. ${ }^{m 8}$ Far from evidencing congressional intent to preclude Title IXbased Section 1983 claims, then, the existence of other civil rights statutes merely highlights the likelihood that discrimination remedies sometimes will overlap.

The "in the enactment itself" requirement of the Sea Clammers line of cases has important implications for Title IX's purported preclusion of Section 1983 claims predicated on Title IX, because courts have created implied rights of action and remedies under Title IX. The only express remedy provided for a Title IX violation is the termination of federal funding by the appropriate federal agency..$^{79}$ In Cannon $v$ University of Chicago, ${ }^{80}$ however, the Supreme Court found an implied right of action under Title IX for plaintiffs who have been discriminated against on the basis of sex. ${ }^{81}$ Thirteen years later, the Court extended Cannon by holding that the implied right of action under Title IX supports a claim for monetary damages as well. ${ }^{82}$ If, instead of limiting their analysis to Title IX's express remedial scheme, courts considered these judicially created remedies when applying the Sea Clammers comprehensiveness test, then the foreclosure question in the Title IX context would be much more difficult. Given the Supreme Courts "in the enactment itself" instructions in the post-Sea Clammers cases, however, lower courts must not consider judicially created remedies. The Court in Wilder was clear that it will "recognize an exception to the general rule that $\S 1983$ provides a remedy for violation of federal statutory rights only when Congress has affirmatively withdrawn the remedy. ${ }^{83}$ Wilder and Sea Clammers, therefore, prevent lower courts from considering even judge-made remedies when applying the Sea Clammers comprehensiveness test. The only remedy that courts may con-

7456 US 512, 521-36 (1982) (holding that Title IX prohibits employment discrimination on the basis of sex in federally funded education programs).

${ }^{78}$ Id at 535-36 $\mathrm{n} 26$.

720 USC \$ 1682. See note 7.

\$4 U1 US 677 (1979).

si Id at 689.

22 Franklin v Gwinnett County Public Schools, 503 US 60, 72-73 (1992).

${ }^{83} 496$ US at 508-09 n 9 (emphasis added) (internal quotations and citations omitted). 
sider is Title IX's express remedy: the withdrawal of federal funding.

Given the strong presumption against statute-based Section 1983 preclusion and given the clear language from the Sea Clammers line of cases that lower courts must limit their comprehensiveness analysis to the express remedial scheme in the statute itself, the conclusion that Title IX does not preclude Section 1983 claims predicated on Title IX is inevitable. The only express remedial provision in Title IX is the termination of federal funding, ${ }^{84}$ and the Supreme Court held in both Wright and Wilder that the remote threat of federal funding termination is not a sufficiently comprehensive remedial scheme to suggest a congressional intent to preclude Section 1983 remedies. ${ }^{85}$ As the Eighth Circuit recognized in Crawford $v$ Davis, ${ }^{86}$ Title IX's sole remedy of terminating federal support is "a far cry from the 'unusually elaborate enforcement provisions' of the statutes at issue in Sea Clammers, which expressly provided for citizen suits. ${ }^{287}$

\section{Title IX Does Not PREClude Section 1983 ClaImS PREDICATED ON CONSTITUTIONAL RIGHTS}

This Part demonstrates that Title IX does not preclude Section 1983 claims predicated on constitutional rights that are not virtually identical to rights conferred by Title IX, nor does it preclude those constitutional claims that are virtually identical to Title IX. The Sixth Circuit in Lillard $v$ Shelby County Board of Education $^{88}$ provides the proper articulation of the two-pronged Smith test: courts may preclude a Constitution-based Section 1983 claim only if (1) the "constitutional claim[ ] [is] "virtually identical" to the statutory . . . claim[ ]," and (2) the "legislative history indicat[es] a congressional intention to preclude reliance on section 1983 as a remedy. ${ }^{989}$ In short, both prongs must be satisfied before a court may preclude a Constitution-based Section 1983 remedy. ${ }^{90}$

20 USC § 1682. See also note 7.

3right, 479 US at 428 ("HUD's authority to audit, enforce annual contributions contracts, and cut off federal funds [are] generalized powers [that] are insufficient to indicate a congressional intention to foreclose $\$ 1983$ remedies."); Wilder, 496 US at 522 (holding that the Wright conclusion is "even more appropriate in the context of the Medicaid Act" because the Secretary's power to curtail federal funds to states is "limited" and "insufficient to demonstrate an intent to foreclose relief... under $\$ 1983^{\prime \prime}$ ).

${ }^{86} 109$ F3d 1281 (8th Cir 1997).

${ }^{82}$ Id at 1284 (internal citation omitted), quoting Sea Clammers, 453 US at 13.

76 F3d 716 (6th Cir 1996).

Id at 723, quoting Smith, 468 US at 1009.

${ }^{\infty}$ See Part I.B. 
A. Section 1983 Claims That Are Not Virtually Identical to Title IX

A victim of sexual harassment by a teacher would have several constitutional Section 1983 claims against the teacher and the school district. She might bring claims based on: (1) the Fourteenth Amendment right to due process, alleging a denial of a fair hearing in which to bring her complaint; (2) the liberty interest in bodily integrity under the substantive due process right in the Fourteenth Amendment; and (3) the right under the Equal Protection Clause of the Fourteenth Amendment to be free from discrimination on the basis of sex. Because Title IX confers on plaintiffs a right to be free from discrimination on the basis of sex, ${ }^{91}$ the plaintiff"s third Constitution-based Section 1983 claim is "virtually identical" to the right conferred by Title IX. Title IX's preclusive effects on the plaintiff's third claim, therefore, will be addressed in the next Part regarding virtually identical Section 1983 claims. This leaves the question of whether Title IX precludes either of the plaintiff's two remaining Section 1983 constitutional claims.

A court confronted with these remaining Constitution-based Section 1983 claims must determine whether either claim is virtually identical to the right under Title IX against discrimination on the basis of sex. The Smith Court did not define the terms "virtually identical,"92 and the Court has not applied the Smith test to a Constitution-based Section 1983 claim since. Similarly, the lower courts have not defined "virtually identical" in any of the Section 1983 preclusion cases involving Title IX. ${ }^{93}$ Courts, therefore, should apply the plain meaning of "virtually identical." Accordingly, neither procedural nor substantive due process rights are identical to, or even virtually identical to, rights under Title IX, which affords protection against discrimination on the basis of sex. ${ }^{94}$ Consequently, if a plaintiff brings procedural and substantive due process claims under Section 1983, those claims would not be precluded by Title IX, for they do not satisfy the first prong of the Smith test.

${ }^{91} 20$ USC $\S 1681$ (a) ("No person in the United States shall, on the basis of sex . . . be subjected to discrimination under any education program or activity receiving Federal financial assistance.").

${ }^{2} 468$ US at 1009.

${ }^{2}$ See text accompanying notes 53-58.

24 The only types of constitutional claims that would comport with the plain meaning of "virtually identical" are equal protection-based ones, because only those types of claims would be the same as the antidiscrimination rights conferred by Title IX. 


\section{B. Section 1983 Claims That Are Virtually Identical to Title IX}

A Section 1983 claim predicated on the right under the Equal Protection Clause to be free of discrimination on the basis of sex involves a right that is identical to the antidiscrimination right created by Title IX itself. Therefore, the preclusion analysis for equal protection-based Section 1983 claims must look to the second prong of the Smith test, "whether Congress intended that [Title IX] be the exclusive avenue through which a plaintiff may assert [constitutional] claims. ${ }^{995}$

In Smith, the plaintiffs brought Section 1983 claims predicated on their rights under the Due Process and Equal Protection Clauses of the Fourteenth Amendment, and both claims were deemed "virtually identical" to rights conferred by the EHA. ${ }^{96} \mathrm{Ap}$ plying the second prong of the Smith test, the Court held that the "carefully tailored administrative and judicial mechanism" set out in the EHA provided evidence that Congress intended plaintiffs to pursue their constitutional claims through the EHA itself. $^{97}$ Specifically, EHA procedures required that hearings conducted by the state be fair and adequate and 'effect Congress' intent that each child's individual educational needs be worked out through a process that begins on the local level and includes ongoing parent involvement, detailed procedural safeguards, and a right to judicial review. ${ }^{\text {}}$

Unlike the detailed remedial procedures of the EHA, however, Title IX's sole statutory remedy is the termination of federal funding. ${ }^{99}$ Title IX, therefore, lacks the carefully tailored administrative scheme that might provide evidence of congressional intent to preclude equal protection-based Section 1983 claims. ${ }^{100}$ In order to complete the preclusion analysis, then, couirts must look to the legislative history of Title IX to determine whether Congress intended to preclude constitutional Section 1983 claims. ${ }^{101}$

In Cannon, the Supreme Court presented a detailed analysis of the legislative history of Title IX in an effort to determine

$\$ 468$ US at 1009.

${ }^{*}$ Id. The plaintiffs also brought a claim under the Education of the Handicapped Act. See id at 994

${ }^{97}$ Id at 1009.

Id at 1011.

${ }^{\infty}$ See note 7.

${ }^{100}$ The severity of federal funding termination makes actual imposition of the sanction highly unlikely; in fact, such termination "is rarely, if ever, invoked." Lisa E. Key, Private Enforcement of Federal Funding Conditions Under § 1983, 29 UC Davis L Rev 283, 292-93 (1996). Congress understood the rarity of funding termination and fully expected individuals to bring private suits. See Cannon, 441 US at 704-05 \& n 38.

${ }^{101}$ See note 29. 
whether Congress intended the statute to confer a private right of action on plaintiffs. ${ }^{102}$ This analysis sheds light on Smith's congressional intent inquiry. The Cannon court applied the fourfactor test of Cort $v$ Ash ${ }^{103}$ to determine whether Title IX created an implied right of action. Cort's second factor is particularly important, as it asks whether there exists "any indication of legislative intent, explicit or implicit, either to create such a remedy or to deny one. ${ }^{104}$ In answer to this question, the Cannon Court found that "[f]ar from evidencing any purpose to deny a private cause of action, the history of Title IX rather plainly indicates that Congress intended to create such a remedy. ${ }^{105}$ The parallel between the implied right of action inquiry and the Section 1983 preclusion inquiry is critical. The Supreme Court's analysis of Title IX's legislative history found no evidence of congressional intent to preclude private rights of action, suggesting that Congress expected private plaintiffs to bring private suits under Title IX. ${ }^{106}$

Under the second prong of the Smith test, then, the Supreme Court's holding in Cannon that Title IX supports a private right of action necessarily means that Congress must not have intended the threat of funding termination to be the "exclusive avenue" by which plaintiffs could vindicate their constitutional rights. ${ }^{107}$ Therefore, even though an equal protection-based Sec-

${ }^{102} 441$ US at 689-717. For additional analysis of Title IX's legislative history, see Franklin v Gwinnett County Public Schools, 503 US 60, 71-73 (1992); Bell, 456 US at 52030.

${ }^{100} 422$ US 66, 78 (1975). The Court held:

In determining whether a private remedy is implicit in a statute not expressly providing one, several factors are relevant. First, is the plaintiff one of the class for whose especial benefit the statute was enacted ... ? Second, is there any indication of legislative intent, explicit or implicit, either to create such a remedy or to deny one? Third, is it consistent with the underlying purposes of the legislative scheme to imply such a remedy for the plaintiff? And finally, is the cause of action one traditionally relegated to state law ... so that it would be inappropriate to infer a cause of action based solely on federal law?

Id (internal quotations and citations omitted).

${ }^{104}$ Id (emphasis added).

${ }^{106} 441$ US at 694. It should be noted that, since Cannon, the Supreme Court has generally collapsed the four-pronged Cort $v$ Ash test into a single-pronged test of congressional intent. See, for example, Thompson $v$ Thompson, 484 US 174, 189 (1988) (Scalia concurring) ("It could not be plainer that we effectively overruled the Cort $v$. Ash analysis in Touche Ross \& Co. v. Redington [442 US 560, 575-76 (1979)] and Transamerica Mortgage Advisors, Inc. v. Lewis [444 US 11, 18 (1979)], converting one of its four factors (congressional intent) into the determinative factor, with the other three merely indicative of its presence or absence.").

${ }^{108}$ Cannon, 441 US at 711-12 \& n 49.

${ }^{107}$ Smith, 468 US at 1009. Title IX, therefore, is unlike the EHA: Congress did expect plaintiffs to abide by the EHA procedures to vindicate their constitutional rights. See id at 1016. 
tion 1983 claim is identical to the right conferred by Title IX, the statute does not preclude the Section 1983 claim because Congress did not intend the threat of funding termination to be the exclusive avenue for relief. ${ }^{108}$

Allowing plaintiffs to bring Section 1983 constitutional claims that are virtually identical to the rights under Title IX might seem to be both redundant and wasteful. However, courts and commentators have noted that "[t]he inertia of discriminatory traditions . . . can only be curtailed by using a 'full arsenal' of statutory weapons." ${ }^{109}$ In particular, the Supreme Court has held that the coverage of both Section 1983 and Title IX is to be broadly construed, ${ }^{110}$ and, as such, courts should adhere to the general canon of statutory construction that "[statutory] repeals by implication are disfavored." "111 Equal protection-based Section 1983 claims and private Title IX claims may appear redundant, but unless convincing proof can be offered that Congress intended to foreclose one of these avenues, courts ought not preclude either of them.

\section{THE IMPLICATIONS OF TITLE IX'S NONPRECLUSION OF SECTION 1983 CLAIMS}

Based on a faithful application of the Sea Clammers comprehensiveness test and the two-pronged Smith test, Title IX has no preclusive effect on a plaintiff's ability to bring Section 1983 claims, regardless of the right upon which the Section 1983 claim is based. The conclusion that Section 1983 claims are not precluded in Title IX cases has important implications for plaintiffs, defendants, and federal courts, because the capacities to reach certain defendants and the burdens of proof under the two statutes are very different. Specifically, plaintiffs need the Section 1983 remedy both to reach individual, rather than institu-

${ }^{108}$ Accord Lillard, 76 F3d at 723 (holding that both prongs of the Smith test must be met to foreclose Constitution-based Section 1983 claims).

${ }^{109}$ Roy L. Brooks, Use of the Civil Rights Acts of 1866 and 1871 to Redress Employment Discrimination, 62 Cornell L Rev 258, 260 (1977), quoting Johnson v Railway Express Agency, Inc, 421 US 454, 468 (1975) (Marshall concurring in part and dissenting in part). Other courts have held that a plaintiff should be able to bring suit "under as many applicable civil rights statutes as the facts of his case permit irrespective of the actual or potential overlap of statutory remedies." Johnson v Ballard, 644 F Supp 333, 337 (N D Ga 1986), quoting Nilsen $v$ City of Moss Point, 701 F2d 556, 561 (5th Cir 1983).

${ }^{110}$ See Golden State Transit Corp v City of Los Angeles, 493 US 103, 105 (1989) ("We have repeatedly held that the coverage of [Section 1983] must be broadly construed."); Bell, 456 US at 521 ("There is no doubt that if we are to give Title IX the scope that its origins dictate, we must accord it a sweep as broad as its language." ), quoting United States $v$ Price, 383 US 787, 801 (1966).

"Hagen $v$ Utah, 510 US 399, 416 (1994). See also note 70. 
tional, defendants and to take advantage of the more lenient burden of proof under Section 1983 for establishing supervisory liability.

\section{A. Proper Defendants Under Title IX and Section 1983}

The conclusion that Title $\mathrm{IX}$ has no preclusive effect on Section 1983 claims has important consequences for plaintiffs and the defendants they attempt to sue. Plaintiffs alleging sexual harassment in schools may have a long list of potential defendants, including classmates (if peer sexual harassment is involved), teachers, the principal, the superintendent, and individual members of the school board, as well as the school district and the municipality in which it operates. Section 1983 allows a plaintiff to sue all defendants in their personal capacities, ${ }^{112}$ but whether individuals may be sued under Title IX remains an open question. ${ }^{113}$ Although one lower court has held that individuals are proper defendants under Title $\mathrm{IX}^{114}$ most courts have held that Title IX precludes a cause of action against individuals "because they are not recipients of federal funds within the meaning of Title IX and its implementing regulations. ${ }^{.115}$ If individuals cannot be sued under Title IX,116 and if-contrary to the conclusion of this Comment-Title IX precludes all Section 1983 claims, then the long list of potential defendants is reduced to the school district and the municipality. Section 1983 preclusion, therefore, would deny the plaintiff the ability to assert her constitutional

\footnotetext{
${ }^{112}$ Monroe v Pape, 365 US 167, 180-83 (1961).

"'see Diane Heckman, On the Eve of Title IX's 25th Anniversary: Sex Discrimination in the Gym and Classroom, 21 Nova L Rev 545, 551-52 \& n 27, 660 (1997).

"Mennone, $889 \mathrm{~F}$ Supp at 56.

${ }^{115}$ Nelson $v$ Temple University, 920 F Supp 633, 638 n 9 (E D Pa 1996). See also Lipsett $v$ University of Puerto Rico, 864 F2d 881, 901 (1st Cir 1988); Clay $v$ Board of Trustees of Neosho County Community College, 905 F Supp 1488, 1495 (D Kan 1995); Garza $v$ Galena Park Independent School District, 914 F Supp 1437, 1438 (S D Tex 1994); Mann v University of Cincinnati, 864 F Supp 44, 47-48 (S D Ohio 1994); Slaughter $v$ Waubonsee Community College, 1994 US Dist LEXIS 16621, *6 (N D Ill); Doe v Petaluma City School District, 830 F Supp 1560, 1563 (N D Cal 1993), revd on other grounds, 54 F3d 1447 (9th Cir 1995), and reconsidered, 949 F Supp 1415 (N D Cal 1996); Floyd v Waiters, 831 F Supp 867, 876 (M D Ga 1993).

${ }^{118}$ It is difficult to predict how the Supreme Court would decide the issue of individual liability under Title IX. The Court did not foreclose the possibility that individuals may be proper defendants under Title IX in either Cannon, 441 US at 677, or Franklin $v$ Gwinnett County Public Schools, 503 US 60, 60 (1992). Although the Cannon majority never made the distinction between individual and institutional defendants, Justice White's dissent suggests that at least he thought that the Cannon majority would permit individuals to be sued under Title IX. Justice White argues that, contrary to the majority's findings, "Congress did not intend to create a private remedy for discrimination practiced not under color of state law but by private parties or institutions." 441 US at 724 (White dissenting) (emphasis added).
} 
rights against any of the individual wrongdoers involved in the case.

None of the circuit courts that has addressed the Section 1983 preclusion issue in the context of Title IX has considered the impact of preclusion analysis on the ability of plaintiffs to sue certain defendants. Although the Sea Clammers and Smith tests do not involve such considerations explicitly, the tests do embody Section 1983's overarching objective of protecting the rights of individuals against the constitutionally impermissible conduct of individuals acting under color of state law. ${ }^{117}$

\section{B. Supervisory Liability Under Title IX and Section 1983}

The preclusive effects of Title IX also have a significant impact on the ability of plaintiffs to hold supervisory officials and institutions liable for the conduct of subordinates. Under Section 1983, supervisory officials and institutions cannot be held vicariously liable under a respondeat superior theory. ${ }^{118}$ Instead, plaintiffs asserting Section 1983 actions against supervisory officials in their individual capacities generally must show a form of gross negligence amounting to deliberate indifference in order to establish liability. ${ }^{119}$ Plaintiffs asserting Section 1983 claims against institutions for the conduct of their subordinates must establish that an institutional policy or custom was the "moving force" behind the plaintiff's injury. ${ }^{120}$

After the Supreme Court's recent decision in Gebser $v$ Lago Vista Independent School District, ${ }^{121}$ plaintiffs will find it much more difficult to prove supervisory liability under Title IX than under Section 1983. In Gebser, the Supreme Court held that, in

${ }^{11}$ See, for example, Mitchum $v$ Foster, 407 US 225, 239 (1972) ("Section 1983 opened the federal courts to private citizens, offering a uniquely federal remedy against incursions under the claimed authority of state law upon rights secured by the Constitution and laws of the nation."); Monroe, 365 US at 179-80 (establishing individual liability against those acting under color of state law who deprive any citizen of his rights under the Constitution or federal laws).

${ }^{118}$ Monell v Department of Social Services, 436 US 658, 694 (1978).

${ }^{11}$ The law is unsettled as to the precise standard for supervisory liability under Section 1983. Most courts have applied a deliberate-indifference-plus-causation standard. See, for example, Lipsett, 864 F2d at 914 (applying a "gross negligence amounting to deliberate indifference" standard); Stoneking $v$ Bradford Area School District, 882 F2d 720, 724 (3d Cir 1989) (applying a "reckless indifference" standard); Doe v Taylor Independent School District, 15 F3d 443, 454 (5th Cir 1994) (applying a "deliberate indifference" standard); Gates v Unified School District, 996 F2d 1035, 1041 (10th Cir 1993) (same).

${ }^{120}$ Board of the County Commissioners $v$ Brown, 117 S Ct 1382, 1388 (1997) ("The plaintiff must ... demonstrate that, through its deliberate conduct, the municipality was the 'moving force' behind the injury alleged. That is, a plaintiff . . . must demonstrate a direct causal link between the municipal action and the deprivation of federal rights.").

${ }^{121} 118$ S Ct 1989 (1998). 
order for a school district to be liable for the conduct of its subordinates, a plaintiff must establish that the district had actual knowledge of the underlying violation and that it acted with deliberate indifference in failing to prevent the injury. ${ }^{122}$ Presumably, the same standard of Title IX supervisory liability would be applied to individual defendants if the Supreme Court were to hold that individuals were proper defendants under Title IX. ${ }^{123}$

The Supreme Court's actual knowledge plus deliberate indifference test for institutional supervisory liability under Title IX will make it extremely difficult for plaintiffs to meet their burden because sexual offenders often "rely on the silence of their victims." ${ }^{\text {124 }}$ In other words, the secret and embarrassing nature of sexual harassment and abuse might make it unlikely that anyone other than the offender and the victim will have actual knowledge of the occurrences in question. ${ }^{125}$

\section{CONCLUSION}

The Supreme Court case law on Section 1983 preclusion, viewed in light of the history of Section 1983 actions and the policies underlying the statute, leads to the conclusion that Title IX has no preclusive effect on either statute-based or Constitutionbased Section 1983 claims. The driving force behind this conclusion-that Congress did not intend to preclude the Section 1983 cause of action-manifests itself in the general, unelaborate remedial scheme of Title IX as well as the legislative history of the statute, which suggests that Congress fully expected plain tiffs to bring private lawsuits to vindicate their rights. Because congressional intent is the linchpin of both Section 1983 preclusion law and the law of implied rights of action, the fact that the Supreme Court already has found an implied right of action under Title IX compels the same conclusion that has been achieved by the me-

\footnotetext{
${ }^{12}$ Id at 1999.

${ }^{12}$ Although the Court in Gebser did not reach the issue of supervisory liability for individuals under Title IX, its strong language in support of the "actual notice" requirement makes it unlikely that such a requirement would apply to individual defendants as well. Id at 1998-99.

${ }^{124}$ Heckman, 21 Nova L Rev at 635 (cited in note 113).

${ }^{125}$ “[A] group of civil rights organizations led by the National Women's Law Center . . . said in their brief [in Gebser] that because many victims of sexual harassment by teachers felt isolated and afraid to report it, a liability standard that depended on official knowledge would effectively immunize school districts much of the time." Linda Greenhouse, School Districts Are Given a Shield in Sex Harassment, NY Times A1 (June 23, 1998). Indeed, the plaintiff in Gebser testified that she had been afraid to tell anyone about her relationship with the teacher. Id.
} 
thodical framework presented by this Comment. Once courts have found an implied right of action under a particular statute, there can be no Section 1983 preclusion because Congress, by the very definition of an implied right of action, must not have intended to preclude private remedies. 